\title{
Low Dosed Curcumin Combined with Visible Light Exposure Inhibits Renal Cell Carcinoma Metastatic Behavior in Vitros
}

\author{
Jochen Rutz ${ }^{1, *}$, Sebastian Maxeiner ${ }^{1}$, Saira Justin ${ }^{1}$, Beatrice Bachmeier $\left.{ }^{2}{ }^{(}\right)$, August Bernd ${ }^{3}$, \\ Stefan Kippenberger ${ }^{3}$, Nadja Zöller ${ }^{3}{ }^{1}$, , Felix K.-H. Chun ${ }^{1}$ and Roman A. Blaheta ${ }^{1}$ \\ 1 Department of Urology, Goethe-University, 60590 Frankfurt am Main, Germany; \\ Sebastian.Maxeiner@kgu.de (S.M.); Justinsaira@hotmail.com (S.J.); Felix.Chun@kgu.de (F.K.-H.C.); \\ Blaheta@em.uni-frankfurt.de (R.A.B.) \\ 2 Institute of Laboratory Medicine, University Hospital, Ludwig-Maximilians-University, 80539 Munich, \\ Germany; Beatrice.bachmeier@tum.de \\ 3 Department of Dermatology, Venereology, and Allergology, Goethe-University, 60590 Frankfurt am Main, \\ Germany; Bernd@em.uni-frankfurt.de (A.B.); Stefan.Kippenberger@kgu.de (S.K.); \\ Nadja.Zoeller@kgu.de (N.Z.) \\ * Correspondence: jochen.rutz@kgu.de; Tel.: +49-69-6301-7109; Fax: +49-69-6301-7108
}

Received: 18 December 2019; Accepted: 25 January 2020; Published: 28 January 2020

check for updates

\begin{abstract}
Recent documentation shows that a curcumin-induced growth arrest of renal cell carcinoma (RCC) cells can be amplified by visible light. This study was designed to investigate whether this strategy may also contribute to blocking metastatic progression of RCC. Low dosed curcumin $(0.2 \mu \mathrm{g} / \mathrm{mL} ; 0.54 \mu \mathrm{M})$ was applied to A498, Caki1, or KTCTL-26 cells for $1 \mathrm{~h}$, followed by exposure to visible light for $5 \mathrm{~min}$ (400-550 nm, $5500 \mathrm{~lx})$. Adhesion to human vascular endothelial cells or immobilized collagen was then evaluated. The influence of curcumin on chemotaxis and migration was also investigated, as well as curcumin induced alterations of $\alpha$ and $\beta$ integrin expression. Curcumin without light exposure or light exposure without curcumin induced no alterations, whereas curcumin plus light significantly inhibited RCC adhesion, migration, and chemotaxis. This was associated with a distinct reduction of $\alpha 3, \alpha 5, \beta 1$, and $\beta 3$ integrins in all cell lines. Separate blocking of each of these integrin subtypes led to significant modification of tumor cell adhesion and chemotactic behavior. Combining low dosed curcumin with light considerably suppressed RCC binding activity and chemotactic movement and was associated with lowered integrin $\alpha$ and $\beta$ subtypes. Therefore, curcumin combined with visible light holds promise for inhibiting metastatic processes in RCC.
\end{abstract}

Keywords: curcumin; renal cell cancer; tumor adhesion; tumor migration; integrins

\section{Introduction}

An estimated 18.1 million new patients worldwide were diagnosed with cancer in 2018, and of these, 9.6 million people died [1]. Characteristics of cancer are the loss of normal cell communication, unlimited cell growth, increased mobility, and the suppression of apoptosis [2]. Migration and motile spread are critical steps in tumor dissemination and progress. As with most tumors, metastasis plays an important role in renal cell carcinoma (RCC) and is the main cause of mortality [3]. Metastases infiltrate bones, lungs, lymph nodes, and less often brain and liver. At first diagnosis, one third of patients already suffer from lymph node and/or organ metastases [4] with another 20 to $30 \%$ developing metastases during therapy [5]. Without treatment, the probability of survival one year after diagnosis of metastasis is only about 50\% [6], and the chances of recovery are poor. More than 5000 people died in Germany due to renal cell carcinoma in 2011 [7] and in a disseminated stage only palliative 
therapy can be provided. The incidence has been increasing in recent decades and has reached a constant level since the 1990s. The mortality is about $8 / 100,000$ for men and $3 / 100,000$ for women [8]. Targeted therapies have been introduced to improve the survival rate, but the prognosis for survival has hardly changed. Aspiring to active involvement, dissatisfaction with conventional medicine, and the hope to reduce unwanted side effects has made patients turn to complementary and alternative medicine (CAM). These approaches range from yoga to mind stimulating music to application of phytopharmacological agents. Up to 50\% of cancer patients in Europe use CAM in addition to, or in place of, conventional medicine $[9,10]$.

The natural compound curcumin (Figure 1) is a component of turmeric, a yellow-orange pigment harvested from the rhizomes of the plant Curcuma longa. Aside from its use as a spice in curry powder, anti-inflammatory, anti-oxidative, and anti-tumorigenic qualities have been demonstrated in vitro and in vivo [11-13], making it interesting for clinical application. Diverse biochemical processes and pathways associated with carcinogenesis are affected and modulated by curcumin [14]. In prostate, lung, breast, and colorectal cancers it has been shown [15] that curcumin affects growth and proliferation by inhibiting cell cycle progression, angiogenesis, and the expression of anti-apoptotic proteins $[14,16,17]$.<smiles>COc1cc(/C=C/C(=O)CC(=O)/C=C/c2ccc(O)c(OC)c2)ccc1O</smiles><smiles>[B]c1ccc(/C=C/C(=O)/C=C(O)/C=C/c2ccc(O)c(OC)c2)cc1OC</smiles>

Figure 1. Chemical structure of curcumin $\left(\mathrm{C}_{21} \mathrm{H}_{20} \mathrm{O}_{6}\right),(\mathbf{A})$ shows keto and (B) enol form [18].

However, due to poor water solubility, low absorption, rapid metabolism and elimination, curcumin has low bioavailability, hampering its clinical use $[19,20]$. To improve bioavailability several approaches have been employed, such as wrapping lipophilic curcumin in liposomes, micelles, solid lipid nanoparticles, or polymer conjugates [21-23]. Likewise a range of analogues play a role in enhancing the bioavailability of curcumin [24]. Although some approaches have been successful, further improvement in bioavailability would be beneficial $[22,25]$.

The present study continues a previous investigation on an RCC cell model demonstrating that exposing curcumin treated cells to visible light considerably enhances curcumin's potential to suppress tumor growth and proliferation [26]. Since metastasis, rather than that the growth of the primary tumor is the main cause of mortality, a therapeutic strategy blocking metastatic progression was investigated here. For this purpose, the influence of low dosed curcumin combined with visible light on adhesion and chemotaxis, as well as on intra- and extracellular integrin expression and signaling, was evaluated using a panel of three RCC cell lines.

\section{Results}

\subsection{Curcumin Uptake}

Curcumin uptake studies were carried out using $4 \mu \mathrm{g} / \mathrm{mL}$ curcumin instead of $0.2 \mu \mathrm{g} / \mathrm{mL}$. This was necessary, since the fluorescence intensity of $0.2 \mu \mathrm{g} / \mathrm{mL}$ curcumin was too low to provide high quality images for confocal microscopy and optimum fluorescence detection by FACS analysis. Using $4 \mu \mathrm{g} / \mathrm{mL}$, curcumin was rapidly incorporated into the cells following administration. In A498 cells, maximum 
fluorescence intensity was noted after $50 \mathrm{~min}$, whereas a plateau phase was reached after $40 \mathrm{~min}$ in Caki1 and already after 20 min in KTCTL-26 cells (Figure 2A). Confocal microscopy demonstrated homogenous cytoplasmic distribution of curcumin in all three cell lines with accumulation along the nuclear membrane (Figure 2B, solid arrows). Curcumin was also visualized within the nucleus (Figure 2B, dashed arrows).
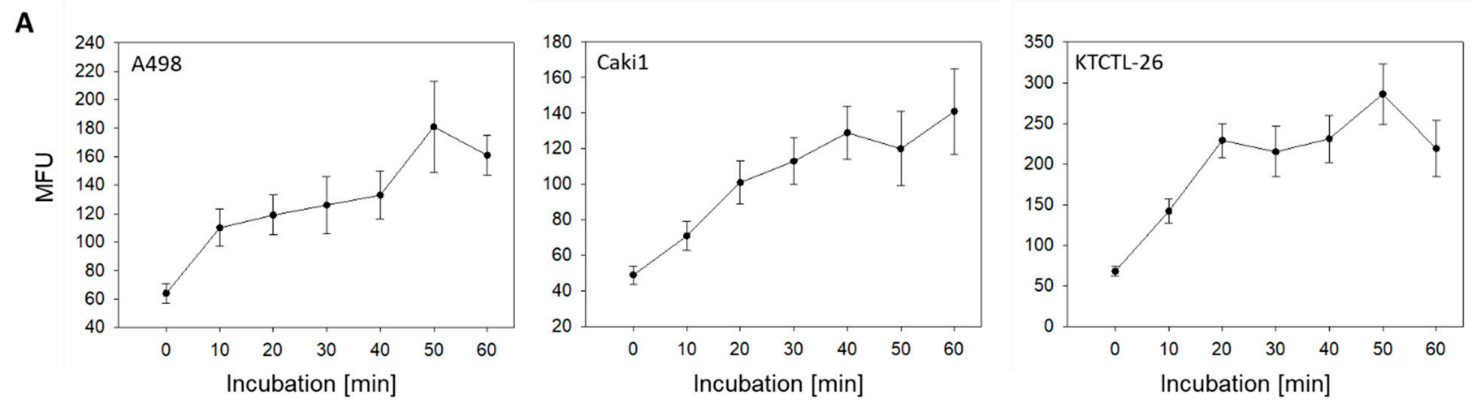

B

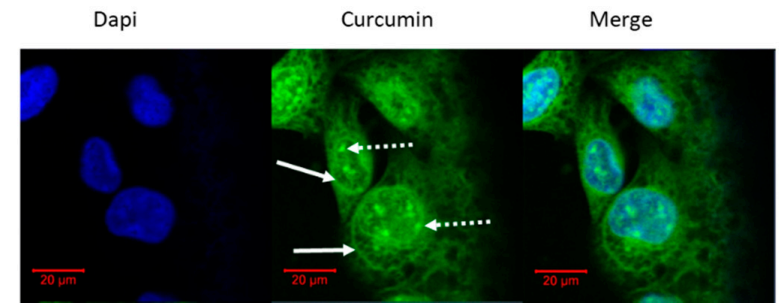

Figure 2. (A) Curcumin uptake in A498, Caki1, KTCTL-26 cells. Each value is the mean \pm SD (standard deviation) of three independent experiments. (B) Intracellular distribution of curcumin $(4 \mu \mathrm{g} / \mathrm{mL})$ in A498 cells (representative for all three cell lines). Fluorescence shown by confocal laser-scanning microscopy after $60 \mathrm{~min}$. Solid arrows: accumulation of curcumin along the nuclear membrane, dashed arrows: accumulation of curcumin within the nucleus. MFU = mean fluorescence units, DAPI = 4',6-Diamidine-2' -phenylindole dihydrochloride.

\subsection{Tumor Cell Adhesion and Binding Behavior}

Adhesion of all three cell lines to HUVECs was blocked by combining $0.2 \mu \mathrm{g} / \mathrm{mL}$ curcumin with visible light (Figure 3A). The number of cells attached after $2 \mathrm{~h}$ (mean adhesion $/ \mathrm{mm}^{2}$, controls versus curcumin $^{\text {Light }}$ ) was: $62.8 \pm 5.3$ versus $20.6 \pm 4.1$ for A498; $40.6 \pm 7.0$ versus $9.2 \pm 2.0$ for Caki1; $40.6 \pm 6.7$ versus $14.4 \pm 3.4$ for KTCTL-26. Light exposure alone or curcumin alone had no more effect on adhesion than the addition of cell medium as a control. A similar response was seen in the binding behavior to immobilized collagen. Neither curcumin nor light exposure alone led to significant alterations of A498, Caki1, or KTCTL-26 cell binding, compared to the untreated controls. Combined use of curcumin and light was associated with a distinct attenuation in the tumor cell attachment rate, with maximum effects exerted on Caki1 cells (17.8 $\pm 6.0 \%$, compared to the $100 \%$ control; Figure $3 \mathrm{~B})$. 
A
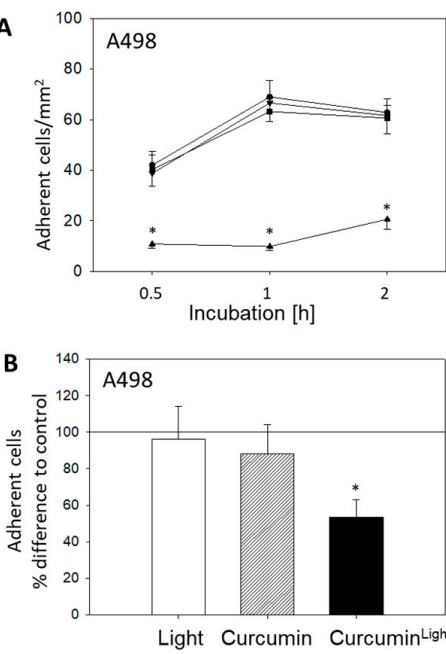
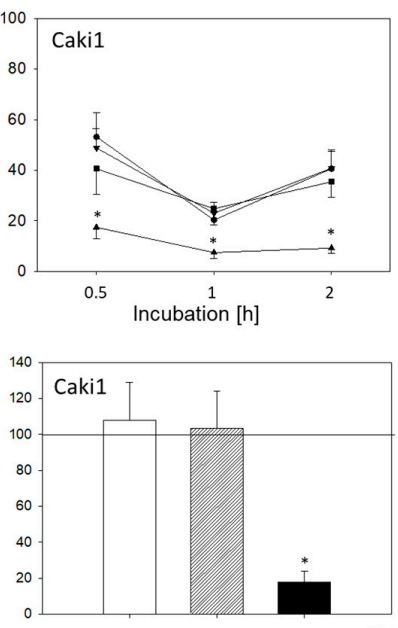

Light Curcumin Curcumin Ligh
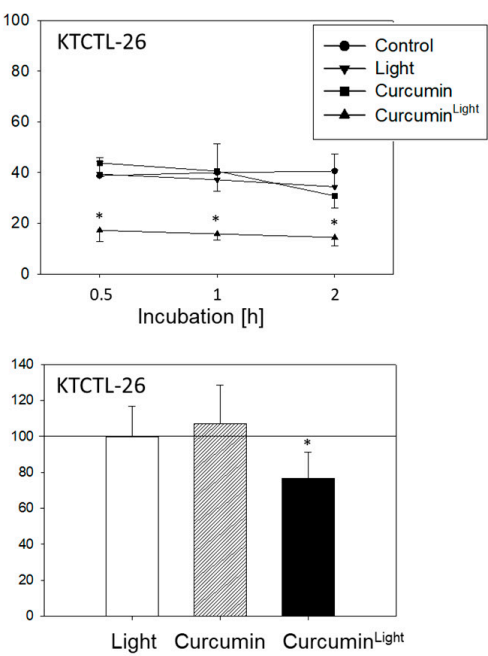

Figure 3. Influence of curcumin $(0.2 \mu \mathrm{g} / \mathrm{mL})$, light, or curcumin ${ }^{\text {Light }}$ on adhesion of RCC cells to HUVECs (A) and (B) collagen. Five separate fields of $0.25 \mathrm{~mm}^{2}$ were counted at 200× magnification (means $\pm \mathrm{SD}, n=6$ ). Control was added cell medium and is indicated by the line at $100 \%$ in (B).

* indicates significant difference to controls $(p=0.00512)$.

\subsection{Chemotaxis and Migration}

Figure $4 \mathrm{~A}$ shows that neither treatment with light nor cultivation of the tumor cells with curcumin influenced chemotactic movement towards a serum gradient. A distinct down-regulation of chemotaxis was induced when the tumor cells were exposed to low-dosed curcumin with light. This response became evident in all three cell culture systems with the order KTCTL-26 $(12.7 \pm 3.6 \%)>$ Caki1 $(20.9 \pm 5.0 \%)>$ A498 $(47.6 \pm 9.6 \%)$, each compared to the $100 \%$ control; Figure $4 \mathrm{~A}$.
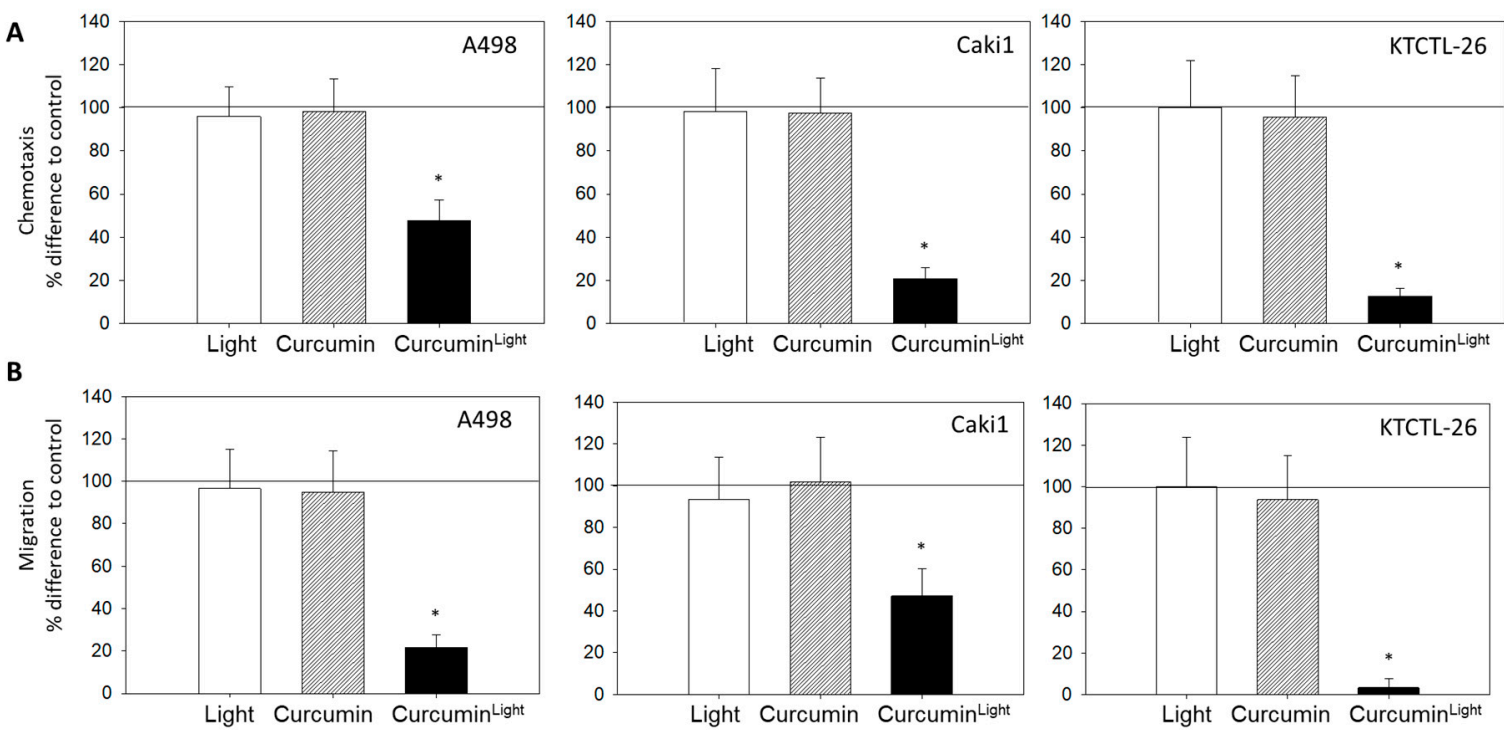

Figure 4. Influence of curcumin $(0.2 \mu \mathrm{g} / \mathrm{mL})$, light, or curcumin ${ }^{\text {Light }}$ on chemotaxis towards a serum gradient (A) and migration through a collagen matrix (B). Endpoints after $24 \mathrm{~h}$. Untreated control cells were set to $100 \%$, indicated by a line drawn at $100 \%$. 5 separate fields of $0.25 \mathrm{~mm}^{2}$ were counted at $200 \times$ magnification (means $\pm \mathrm{SD}, n=6$ ). ${ }^{*}$ indicates significant difference to controls $(p=0.00512)$.

Tumor cell migration through a collagen matrix towards a serum gradient was also evaluated. Curcumin or light alone did not alter the trans-migration rate, whereas curcumin ${ }^{\text {Light }}$ did (Figure 4B). 
Migration was nearly completely abrogated in KTCTL-26 cells $(3.4 \pm 4.2 \%$, compared to the $100 \%$ control).

\subsection{FACS Analysis of Iintegrin Surface Expression}

Different integrin expression patterns were apparent for the different tumor cell lines. In A498 cells, the integrin subtypes $\alpha 3, \beta 1$, and $\beta 3$ were expressed to the highest extent at the cell surface. Distinct fluorescence intensity was also recorded for $\alpha 1$ and $\alpha 5$. The subtypes $\alpha 2, \alpha 4$, and $\alpha 6$ were detected moderately, whereas $\beta 4$ was not expressed at all (Figure 5).

A498
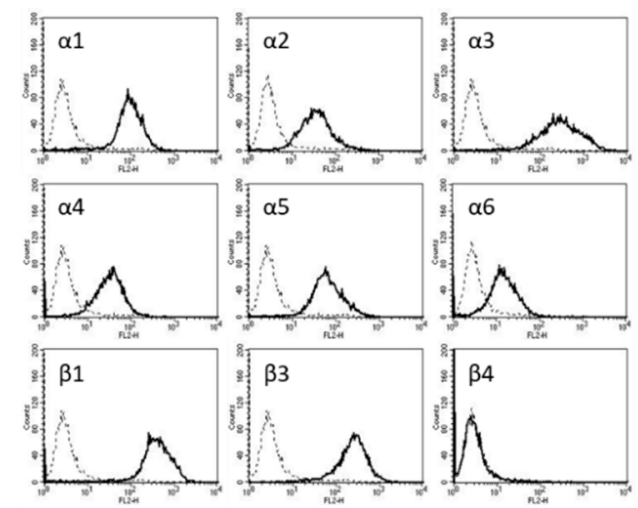

KTCTL-26
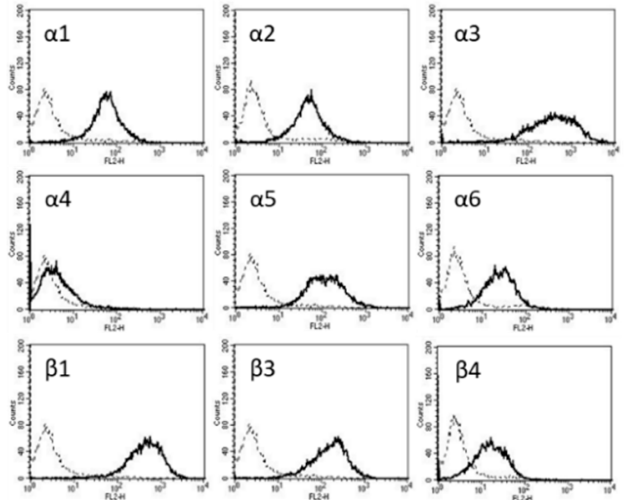
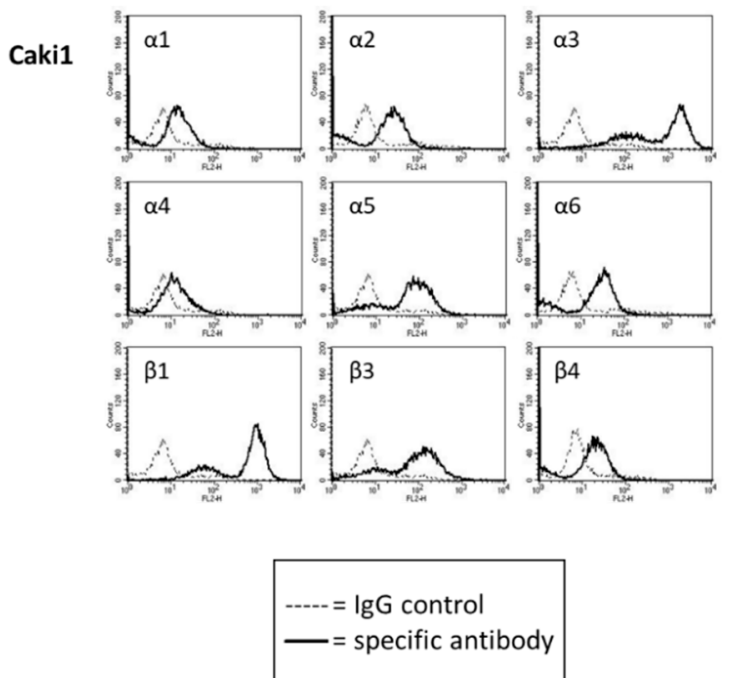

Figure 5. Surface expression of $\alpha$ and $\beta$ integrins on A498, Caki1, and KTCTL-26 cells. Measured by Figure 1. PE, IgG2a-PE and IgG2b-PE (dashed line). The abscissa shows the relative logarithmic distribution of the relative fluorescence intensity of $\alpha 1-\alpha 6$ and $\beta 1, \beta 3$, and $\beta 4$. The ordinate shows cell number. 10,000 cells were counted. Figure is representative for $n=6$.

Caki1 cells were characterized by a very strong expression of $\alpha 3$ and $\beta 1$, and a strong expression of $\alpha 5$ and $\beta 3$. $\alpha 2$ and $\alpha 6$, as well as $\beta 4$, were also present at the surface membrane. $\alpha 1$ and $\alpha 4$ were only marginally detectable (Figure 5).

Similar to Caki1, $\alpha 3$ and $\beta 1$ were also expressed to the highest extent on KTCTL-26 cells. $\alpha 5$ and $\beta 3$ were distinctly detectable. $\alpha 1, \alpha 2, \alpha 6$, and $\beta 4$ were also detectable (Figure 5). $\alpha 4$ was barely detectable.

The integrin expression level was not modulated by curcumin or light, when applied separately, but significant alterations were evoked by curcumin ${ }^{\text {Light }}$. The surface expression of $\alpha 3, \alpha 5, \beta 1$, and $\beta 3$ was diminished in all three tumor cell lines (A498: $\alpha 3$ : $-14.0 \pm 1.3 \%, \alpha 5:-57.1 \pm 3.7 \%, \beta 1:-23.8 \pm 1.5 \%$, ß3: $-56.7 \pm 4.4 \%$; Caki1: $\alpha 3:-15.9 \pm 0.8 \%, \alpha 5:-18.0 \pm 1.2 \%, \beta 1:-37.3 \pm 2.7 \%, \beta 3:-20.4 \pm 1.5 \%$; KTCTL-26: $\alpha 3:-41.1 \pm 3.7 \%, \alpha 5:-40.2 \pm 2.0 \%, \beta 1:-45.8 \pm 4.0 \%, \beta 3:-25.6 \pm 3.2 \%$; each compared to the $100 \%$ control), while $\alpha 1$ was suppressed in A498 (-48.7 $\pm 2.4 \%)$ and KTCTL-26 cells $(-37.0 \pm 2.2 \%)$. $\alpha 2(-22.1 \pm 1.8 \%)$ and $\alpha 6(-29.1 \pm 1.8 \%)$ were exclusively down-regulated on KTCTL-26 (Figure 6). The influence of curcumin and/or light on $\alpha 4$ and $\beta 4$ was not evaluated, since $\alpha 4$ was not expressed on all cell lines and $\beta 4$ was not expressed on A498 and only slightly expressed on Caki1 and KTCTL-26 cells. 


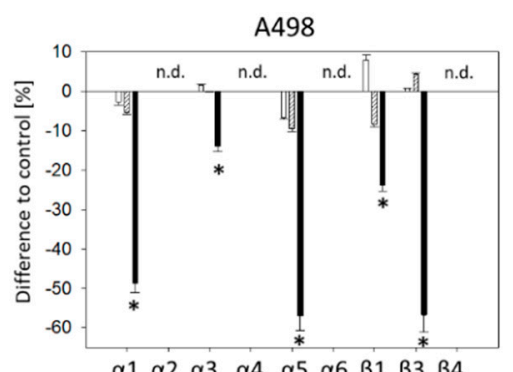

$\begin{array}{llllllllll}\alpha 1 & \alpha 2 & \alpha 3 & \alpha 4 & \alpha 5 & \alpha 6 & \beta 1 & \beta 3 & \beta 4\end{array}$
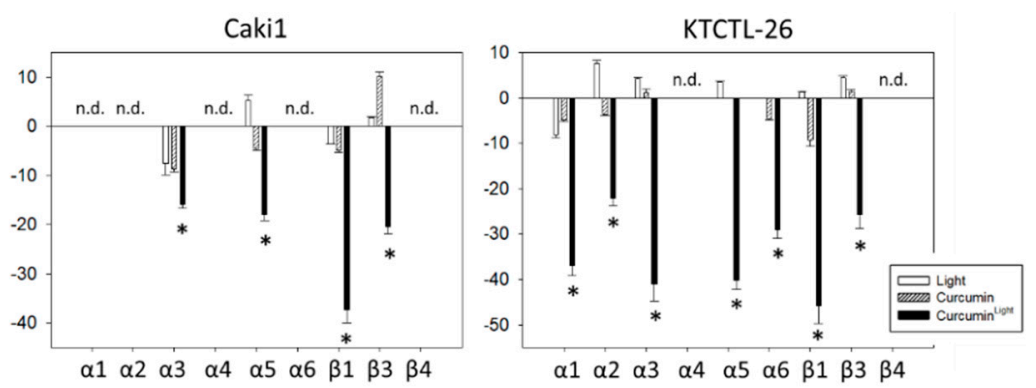

Figure 6. Influence of curcumin $(0.2 \mu \mathrm{g} / \mathrm{mL})$, light, or curcumin ${ }^{\text {Light }}$ on the integrin expression profile of A498, Caki1, and KTCTL-26 cells. The untreated control is set to $0 \%$ (line drawn at $0 \%$ ). Values are means $\pm \mathrm{SD}, n=6$. ${ }^{*}$ indicates significant difference to controls $(p=0.00512)$. n.d. $=$ not or hardly detectable.

\subsection{Western Blot Analysis}

Figure 7 illustrates changes in the integrin protein content including ILK, FAK, and pFAK after exposure to curcumin, light, or curcumin ${ }^{\text {Light }}$ (whole blots are shown in Figure S1). Figure 8 shows the respective pixel density data (pixel density and $p$-values are shown in Figure S2). Exposing the tumor cells to visible light did not lead to distinct protein modifications, excepting $\alpha 2$ and $\beta 1$, both of which were up-regulated in KTCTL-26 cells, and pFAK which was diminished in KTCTL-26 and elevated in A498 cells, compared to the untreated controls. Curcumin alone also had no specific effect on protein expression, excepting $\beta 3$, which was up-regulated in Caki1 cells, and $\alpha 5$, which was enhanced in KTCTL-26 cells. In contrast, a strong response became evident when the tumor cell lines were treated with curcumin ${ }^{\text {Light }}$. Here, compared to the controls, exposure to light alone or treatment with curcumin alone, the following proteins were reduced: A498- $\alpha 1,-\beta 1,-\beta 3$; Caki1- $\alpha 5,-\beta 1$; KTCTL-26- $\alpha 1,-\alpha 2,-\beta 1$, - $\beta 3$. ILK, FAK, and pFAK were suppressed in all cell lines when exposed to curcumin ${ }^{\text {Light }}$.

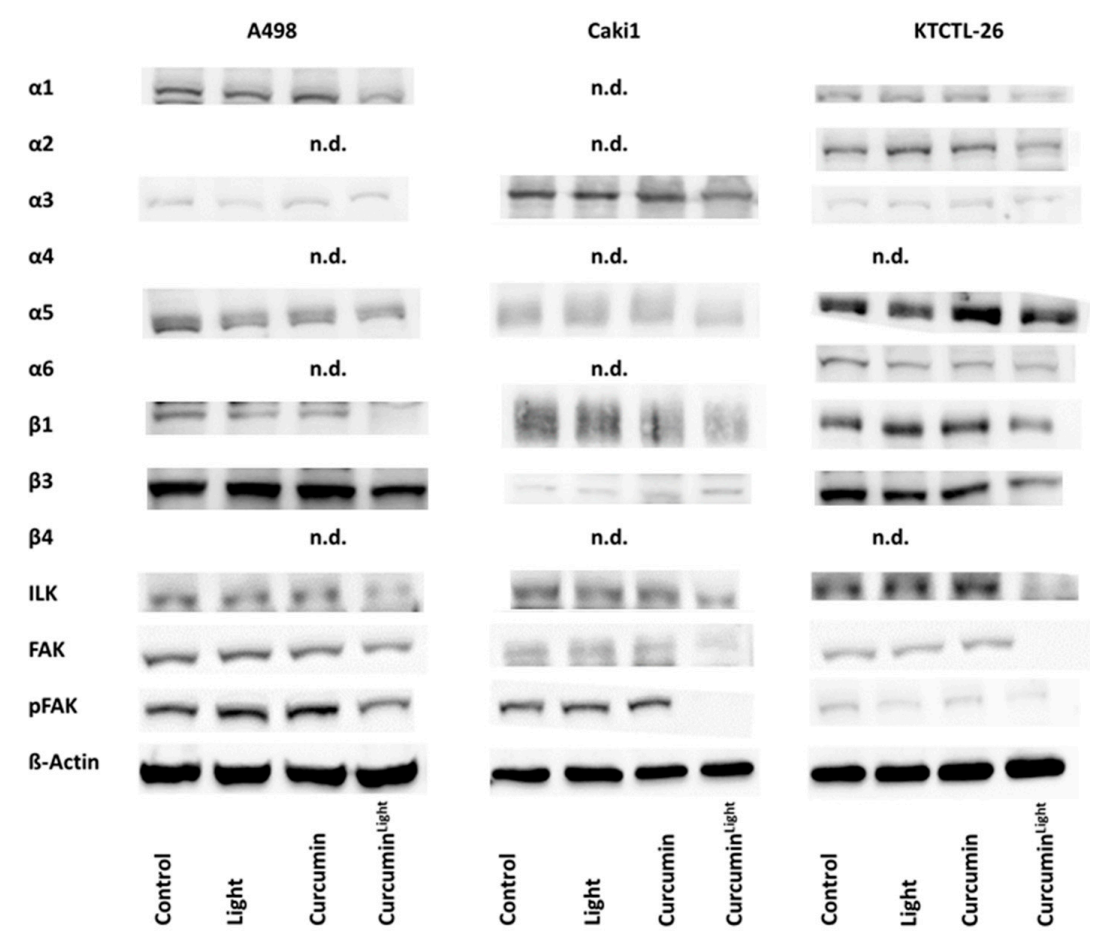

Figure 7. Western blot of $\alpha$ and $\beta$ integrins, ILK and pFAK depending on the influence of curcumin $(0.2 \mu \mathrm{g} / \mathrm{mL})$, light, and curcumin ${ }^{\text {Light }}$ on A498, Caki1, and KTCTL-26 cells. Protein levels were measured $24 \mathrm{~h}$ after respective treatments. All bands are representative of $n=3$. $\beta$-actin served as loading control and is representatively shown once. $50 \mu \mathrm{g}$ were used per sample. n.d. = not detectable. 

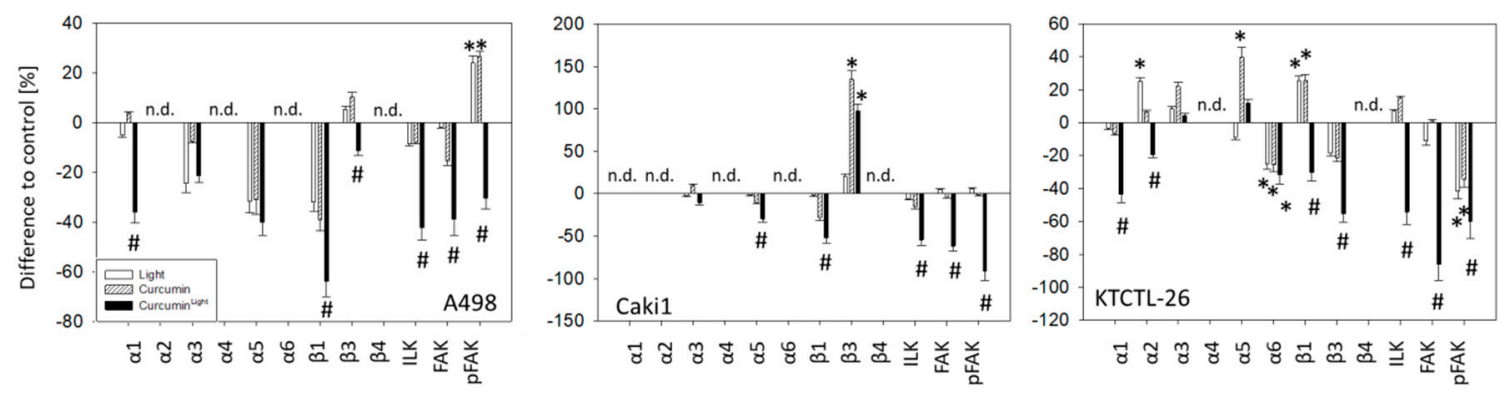

Figure 8. Pixel density of Western blot of $\alpha$ and $\beta$ integrins, ILK and pFAK, depending on the influence of curcumin $(0.2 \mu \mathrm{g} / \mathrm{mL})$, light, or curcumin ${ }^{\text {Light }}$ on A498, Caki1, and KTCTL-26 cells. Values are means $\pm \mathrm{SD}, n=3$. * indicates significant difference to the untreated control (line drawn at $0 \%$ ) and \# indicates significant difference to light alone or curcumin alone. n.d. = not detectable.

\subsection{Integrin Blockage}

The FACS analysis demonstrated that curcumin ${ }^{\text {Light }}$ induces the loss of $\alpha 3, \alpha 5, \beta 1$, and $\beta 3$ in all tumor cell lines. Therefore, the surface expression of $\alpha 3, \alpha 5, \beta 1$, and $\beta 3$ was blocked to evaluate the physiological and pathological relevance of these integrin subtypes on adhesion (Figure 9A) and chemotaxis (Figure 9B).

A

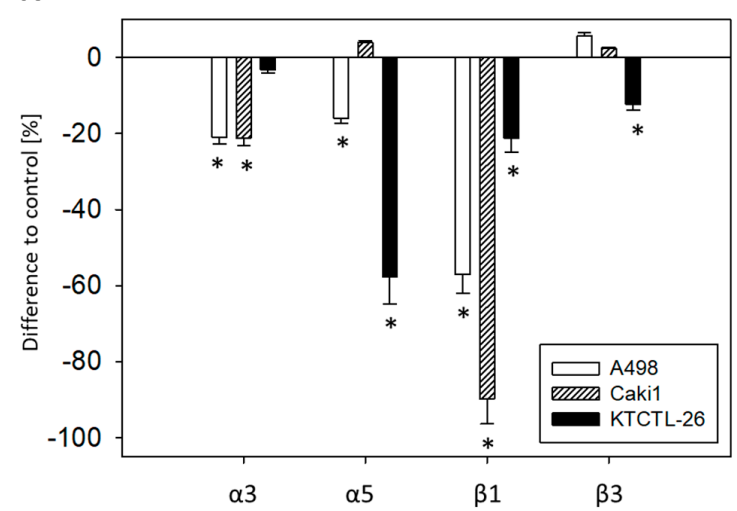

B

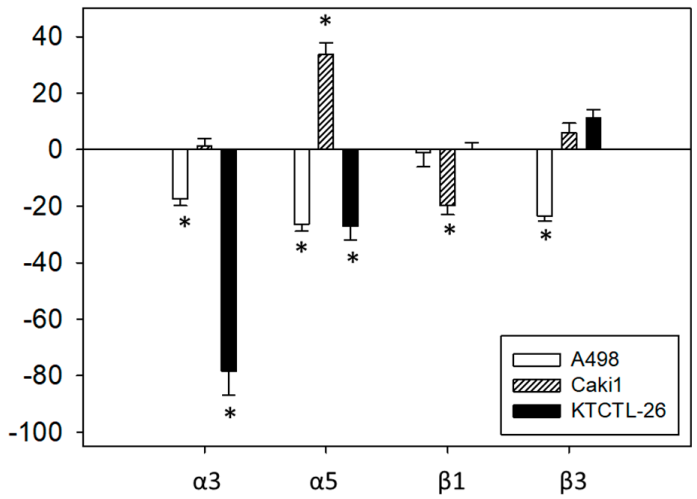

Figure 9. Adhesion to collagen (A) and chemotaxis (B) of A498, Caki1, and KTCTL-26 cells after blockade of integrins $\alpha 3, \alpha 5, \beta 1$, or $\beta 3$. The untreated control is set to $0 \%$ (line drawn at $0 \%$ ). 5 separate fields of $0.25 \mathrm{~mm}^{2}$ were counted at $200 \times$ magnification (means $\pm \mathrm{SD}, n=6$ ). ${ }^{*}$ indicates significant difference to controls $(p=0.00512)$.

Blocking integrin $\alpha 3$ was associated with reduced A498 and Caki1 adhesion (A498: $-20.9 \pm 1.9 \%$; Caki1: $-21.2 \pm 2.0 \%$ ) and diminished A498 and KTCTL-26 chemotaxis (A498: $-17.5 \pm 2.3 \%$; KTCTL-26: $-78.3 \pm 8.6 \%$ ). Blocking $\alpha 5$ down-regulated A498 and KTCTL-26 adhesion (A498: $-16.0 \pm 1.3 \%$; KTCTL-26: $-57.6 \pm 7.3 \%$ ) and chemotaxis (A498: $-26.4 \pm 2.4 \%$; KTCTL-26: $-27.0 \pm 5.0 \%$ ), whereas chemotaxis of Caki1 was enhanced $(+33.7 \pm 4.1 \%)$. Surface blocking of $\beta 1$ suppressed adhesion of all cell lines in the order Caki1 $(-89.7 \pm 6.7 \%)>$ A498 $(-57.1 \pm 1.0 \%)>$ KTCTL-26 $(-21.3 \pm 3.6 \%)$, and diminished Caki1 chemotaxis $(-19.7 \pm 3.3 \%)$. $\beta 3$ blockade down-regulated KTCTL-26 adhesion $(-12.3 \pm 1.0 \%)$ and A498 chemotaxis $(-23.5 \pm 1.9 \%)$.

\section{Discussion}

Exposing RCC cells to visible light significantly enhanced curcumin's potential to block adhesion and migration. While low dosed curcumin alone induced no alterations in tumor-endothelial or tumor-matrix interaction, the combination of curcumin plus light did. Photodynamic properties of curcumin are well documented, though the mechanistic background is not fully understood. In general, 
irradiation of a photodynamic molecule with a particular wavelength shifts electrons to higher energy orbitals. This singlet state is unstable, and the electrons return to their ground state by emitting light or heat. However, changes in electron spin can also shift a photodynamic molecule to the triplet state, which then triggers two reactions. The Type 1 reaction produces free radicals and, due to an interaction with oxygen, reactive oxygen species (ROS). The Type 2 reaction results in singlet oxygen that can interact with specific intracellular molecules [27]. Whether this mechanism also holds true for curcumin is not yet clear. Laubach et al. assumed a shift in the cellular redox balance by boosting $\mathrm{H}_{2} \mathrm{O}_{2}$ generation [28]. Bruzell et al. speculated that curcumin may photo-generate reduced forms of molecular oxygen [29]. In our own pilot experiments, treating curcumin with light prior to application did not enhance the anti-tumor effect of curcumin, compared to the application of curcumin without light. In line with this, intra-peritoneal injections of curcumin with or without light induced the same effect on nerve injury repair in a mouse model [30]. The phenomenon could be attributed to the unstable excitation state of irradiated curcumin with a very short half-life, although other mechanisms cannot be excluded. Bernd has suggested that a light-dependent energy transfer via curcumin may enhance the influence of this compound on tumor relevant protein functions [18]. Niu et al. assumed photo-activation to be an essential amplification factor when taking advantage of curcumin at low concentrations [31].

Low-dosed curcumin $(0.2 \mu \mathrm{g} / \mathrm{mL})$ combined with light profoundly blocked RCC cell adhesion to HUVEC, while even $5 \mu \mathrm{M}$ of free curcumin without light could not alter the binding of prostate cancer cells to HUVEC [32]. In the present study, since the number of attached RCC cells was maximally reduced after $30 \mathrm{~min}$, with no further diminishment at 1 or $2 \mathrm{~h}$, curcumin ${ }^{\text {Light }}$ seems to exert its effect in the initial attachment phase. A strong benefit of adding light to a low curcumin concentration $(0.2 \mu \mathrm{g} / \mathrm{mL})$ was also evident in the tumor cell-matrix attachment, where curcumin ${ }^{\text {Light }}$ (but not curcumin alone) down-regulated the binding of all cell lines to immobilized collagen. Herman et al. have demonstrated adhesion blocking effects of curcumin on prostate cancer cells [33] and others have demonstrated that curcumin suppresses binding of esophageal [34], skin [35], or breast cancer [36] to extracellular matrix proteins. In all cases, high concentrations of 5-50 $\mu \mathrm{M}$ curcumin were necessary to exert therapeutic efficacy. Until now, the relevance of curcumin to RCC adhesive processes had not been documented.

The benefit of visual light on curcumin's bioavailability was also seen in regard to chemotaxis and migration. $0.2 \mu \mathrm{g} / \mathrm{mL}$ curcumin ${ }^{\text {Light }}$, but not $0.2 \mu \mathrm{g} / \mathrm{mL}$ curcumin alone, profoundly reduced motile crawling of all three RCC cell lines. The invasion blocking effect of curcumin is important, since once metastasized, cancer is difficult to treat, and the extent of metastasis rather than the primary cancer determines survival. Therefore, application of curcumin ${ }^{\text {Light }}$ might be an innovative concept to accompany established RCC treatment protocols. The relevance of curcumin alone to act on tumor cell invasion has already been shown on other tumor entities, whereby curcumin concentrations of $10 \mu \mathrm{M}$, $15 \mu \mathrm{M}, 50 \mu \mathrm{M}$, or higher have been applied to stop invasion of gastric [37], breast [38], prostate [39], or hepatic cancer cells [40]. Ongoing experiments should, therefore, deal with the question of whether the beneficial effects of light exposure on curcumin may also hold true for these tumor types.

When interpreting the influence of curcumin ${ }^{\text {Light }}$ on adhesion and chemotaxis, it is notable that curcumin $^{\text {Light }}$ considerably blocked adhesion of Caki1, whereas KTCTL-26 adhesion was only slightly suppressed. In contrast, migration properties of KTCTL-26 were suppressed to a maximum, migration of Caki1 was suppressed moderately. Due to these differences, lowered migration does not seem to exclusively be just a consequence of a reduced attachment rate. Rather, curcumin ${ }^{\text {Light }}$ is involved in both the regulation of the mechanical tumor cell-matrix contact and modulation of cytoskeletal structures. Indeed, curcumin has been shown in tumor cell models to disorganize the architecture of actin microfilaments, leading to destabilization and a decrease in F-actin polymerization [41,42]. Dhar et al. assumed an allosteric effect in which curcumin binding at the "barbed end" of actin is transmitted to the "pointed end," where conformational changes disrupt interactions with the adjacent 
actin monomer to interrupt filament formation [43]. There is also evidence that curcumin stops the physical interaction of cortactin with p120 catenin, which then may inhibit migration [44].

Beyond intracellular components, membrane proteins expressed on the cell surface are also relevant for controlling cell movement. Alterations of the integrin $\alpha$ - and $\beta$-expression pattern have been closely associated with altered metastatic activity [45]. Therefore, integrins are considered to be highly relevant treatment targets [46]. The data presented here point to distinct changes of particular integrin subtypes in the presence of curcumin ${ }^{\text {Light }}$, but not in the presence of curcumin alone. Of all integrin members evaluated, surface expression of four subtypes were modified in the same manner in all cell lines; $\alpha 3, \alpha 5, \beta 1, \beta 3$ were all down-regulated by curcumin ${ }^{\text {Light }}$. Since the intracellular $\alpha 3$ protein content was neither reduced in Caki1, nor in KTCTL-26 and A498 cells, $\alpha 3$ might be shed from the surface without intracellular alteration. Shedding may also be relevant for $\alpha 5$ (KTCTL-26) and $\beta 1$ (KTCTL-26). It is hypothesized that the $\beta 3$ protein increase in Caki1 is caused by curcumin ${ }^{\text {Light }}$ inducing a translocation from the cell surface to the cytoplasm.

The relevance of integrins in tumor progression is not completely understood. Integrin $\alpha 3$ is thought to be closely associated with the capacity of RCC for local and distant spread [47]. The same attribute has been linked to integrin $\beta 3$ [48], and based on clinical specimens from tumor patients, $\alpha 3$ as well as $\beta 3$ have been proposed as potential prognostic markers [49,50]. Evidence indicates that the integrin subtype $\alpha 5$ correlates with poor survival [51]. In fact, $\alpha 5$ is the most highly expressed integrin in RCC tissue, compared with adjacent normal renal tissue, and knocking down $\alpha 5$ has been shown to significantly reduce cell migration [52].

Integrin $\beta 1$ also plays an important role in the development of RCC tumors and advanced RCC with metastasis [53], the observation of which has led to the development of volociximab, an anti- $\alpha 5 \beta 1$ integrin monoclonal antibody [54]. The suppressive effect of low dosed curcumin plus light on the integrins $\alpha 3, \alpha 5, \beta 1$, and $\beta 3$ on RCC adhesion, chemotaxis, and migration could (at least in part) be attributed to inhibition of these integrins, which when blocked were shown to inhibit RCC binding and spreading. The inhibition of adhesion or chemotaxis depended on the cell line. $\beta 1$, which was strongly reduced on Caki1 cells by curcumin ${ }^{\text {Light }}$, was also prominently involved in regulating adhesion in this cell line. The integrin $\alpha 5$ subtype, the major regulator of KTCTL-26 adhesion, was also considerably suppressed by curcumin ${ }^{\text {Light }}$ in KTCTL-26 cells. $\alpha 3$ integrin served as a dominant element in reducing KTCTL-26 chemotaxis. The same integrin was also considerably suppressed by curcumin ${ }^{\text {Light }}$. These data could indicate that metastatic tumor progression is controlled by different integrin members, depending on the tumor differentiation status, and that these specific integrins act as main targets for curcumin ${ }^{\text {Light. }}$. This is, however, speculative. A498 chemotaxis depended equally well on $\alpha 3, \alpha 5$, and $\beta 3$. It must also be considered that quantitative alteration of the integrin surface expression, but not activity, was evaluated. Whether integrin loss is associated with a similar loss of activity cannot be judged.

Suppressed integrin $\alpha 3$ was associated with inhibited adhesion in A498 and Caki1 cells but not in KTCTL-26 cells. Chemotaxis was inhibited in A498 and KTCTL-26, but not in Caki1 cells. Suppression of $\beta 3$ exclusively prevented A498 adhesion and KTCTL-26 chemotaxis. Blockade of $\alpha 5$ coupled to an increased chemotaxis rate of Caki1 is paradoxic and difficult to explain, since curcumin ${ }^{\text {Light }}$ evoked $\alpha 5$ inhibition would be expected to contribute to increased motile behavior, which was not the case.

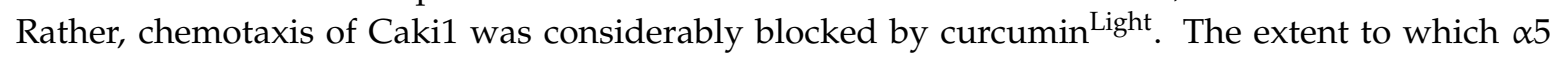
was diminished in Caki1 by curcumin ${ }^{\text {Light }}$ was only $-20 \%$, compared to an $\alpha 5$ reduction in A498 $(-60 \%)$ and KTCTL-26 cells $(-40 \%)$. Speculatively, the moderate alteration of Caki1's $\alpha 5$ surface level by curcumin ${ }^{\text {Light }}$ is of minor relevance for adhesion and migration. Counter regulation should be considered, and this $\alpha 5$ behavior in Caki1 may point to resistance induction.

Aside from the paradoxical role of $\alpha 5$ in Caki1 cells, curcumin ${ }^{\text {Light }}$ is shown here to act on a set of integrin receptors which, in combination, profoundly blocks metastatic progression in vitro. This indicates that the complex process of metastasis is not controlled by only one particular integrin subtype. Rather, several integrins seem to be regulatory elements driving the invasion cascade forward. 
Consequently, blocking a set of relevant integrin members, as curcumin ${ }^{\text {Light }}$ did, might be more effective than blocking just a single integrin.

The therapeutic potential of curcumin is also reflected by its deactivation of FAK. FAK serves as a prominent linker molecule, connecting integrin related signaling with pro-mitogenic and pro-migratory pathways including the Ras-ERK and PI3K/AKT pathway [55]. Performing a mass spectrometry-based system-wide survey of tyrosine phosphorylation in clear cell and papillary RCC human tumors, distinct FAK phosphorylation has been found in all tumors [56]. FAK may also mediate resistance towards the tyrosine kinase inhibitor sorafenib in RCC patients [57]. This opens the possibility that light exposure to curcumin treated RCC cells might not only be an innovative strategy to fight metastatic progression but also to enhance or prolong the response towards a tyrosine kinase inhibitor-based regimen. Curcumin combined with sorafenib or sunitinib has already been demonstrated to synergistically inhibit cancer growth and metastasis in vitro and in vivo [58,59].

The technical aspect of curcumin-light application has been addressed. Introducing an optical fiber into RCC tumors in mice with subsequent laser illumination of the vascular-acting photosensitizer WST11 at $750 \mathrm{~nm}$ or multispectrally at $700-800 \mathrm{~nm}$ has been shown to induce significant necrosis in RCC tissue [60]. Kroeze et al. have suggested using the photosensitizer mTHPC (meso-tetra(hydroxyphenyl)chlorin), which targets both vasculature and tissue and, therefore, may produce a strong combined effect [61]. Exposing the tumor bed to light after tumor resection and curcumin administration has also been discussed in regard to eliminating invisible micro-metastases [62].

\section{Materials and Methods}

\subsection{Cell Culture}

Renal carcinoma Caki1 and KTCTL-26 cell lines, both derived from a clear cell renal cell carcinoma and von Hippel-Lindau (VHL) positive, were purchased from LGC Promochem (Wesel, Germany). A498 cells with disrupted VHL function were derived from Cell Lines Service (Heidelberg, Germany). The tumor cells were grown and subcultured in RPMI 1640 medium supplemented with $10 \%$ fetal calf serum (FCS), 1\% Glutamax (all Gibco/Invitrogen, Karlsruhe, Germany), 2\% HEPES (2-(4-(2-Hydroxyethyl)-1-piperazinyl)-ethansulfonsäure) buffer and 1\% penicillin/streptomycin (both Sigma-Aldrich, München, Germany), at $37^{\circ} \mathrm{C}$ in a humidified $5 \% \mathrm{CO}_{2}$ incubator. Subcultures from passages 5-30 were selected for experimental use.

Human umbilical vein endothelial cells (HUVEC), isolated from human umbilical veins, were grown in Medium 199 (M199; Biozol, Munich, Germany), 10\% FCS, 10\% pooled human serum, $20 \mu \mathrm{g} / \mathrm{mL}$ endothelial cell growth factor (Boehringer, Mannheim, Germany), $0.1 \%$ heparin, $100 \mathrm{ng} / \mathrm{mL}$ gentamycin and $20 \mathrm{mM}$ HEPES-buffer. Subcultures from passages 2 to 6 were selected for experimental use.

\subsection{Drug Dosage and Light Exposure}

Curcumin (Biomol, Hamburg, Germany) was stored at $-20^{\circ} \mathrm{C}$ and diluted prior to use in cell culture medium to a final concentration of $0.2 \mu \mathrm{g} / \mathrm{mL}(0.54 \mu \mathrm{M}) .4 \mu \mathrm{g} / \mathrm{mL}$ curcumin was used to provide high quality images for confocal microscopy and optimum fluorescence detection by FACS analysis. Cells were treated with curcumin for $1 \mathrm{~h}$ and then exposed to visible light for 5 min with $5500 \mathrm{~lx}$ (curcumin ${ }^{\text {Light }}$; $10 \times 40 \mathrm{~W}$ lamps, distance $45 \mathrm{~cm}$, emission spectrum: 400-550 nm) using a Waldmann UV 801AL system (Waldmann, Villingen-Schwenningen, Germany) [18]. To prevent bias effects by the phenol red containing RPMI 1640 based cell culture medium, tumor cells were transferred to phenol red free PBS (phosphate-buffered saline) (Sigma-Aldrich) during light exposure. Thereafter, PBS was replaced by RPMI 1640 and supplements. Control cell cultures received PBS for 5 min without light exposure. To evaluate the effects of low dosed curcumin and light alone, two respective additional controls were employed; tumor cells exposed to light but not to curcumin, and tumor cells exposed to 
curcumin but no light. Following light exposure (including all controls), tumor cells were allowed to recover in complete cell culture medium for $24 \mathrm{~h}$ before starting adhesion and migration experiments.

\subsection{Cellular Curcumin Uptake}

$5 \times 10^{4}$ RCC cells were plated on 6-well multiplates (Sarstedt, Nümbrecht, Germany) and, when grown to sub-confluency, incubated with $4 \mu \mathrm{g} / \mathrm{mL}$ curcumin for different time periods ranging from 10 to $60 \mathrm{~min}$ at $37^{\circ} \mathrm{C}$. Thereafter, the tumor cells were detached, washed three times with PBS $\left(\mathrm{Ca}^{2+}\right.$ and $\mathrm{Mg}^{2+}$ ) and subsequently added to FACS-buffer (PBS $+0.5 \%$ bovine serum albumin, BSA) at $0.5 \times 10^{5}$ cells $/ \mathrm{mL}$. Fluorescence intensity (mean fluorescence units, MFU) of curcumin exposed versus non-exposed cells was then measured by a FACS Canto (BD Biosciences, Heidelberg, Germany) at an absorption of $485 \mathrm{~nm}$ and emission of $514 \mathrm{~nm}$.

\subsection{Intracellular Distribution of Curcumin}

To evaluate intracellular localization of curcumin, tumor cells were incubated with $4 \mu \mathrm{g} / \mathrm{mL}$ curcumin for $60 \mathrm{~min}$, washed with PBS, fixed in cold $\left(-20^{\circ} \mathrm{C}\right)$ methanol/acetone $(50 / 50 \mathrm{v} / \mathrm{v})$ and then washed with blocking buffer (0.5\% BSA in PBS). To prevent photobleaching of curcumin, tumor cells were embedded in Vectashield mounting medium including DAPI (Biozol, Munich, Germany), and viewed using a confocal laser scanning microscope (Zeiss, Oberkochen, Germany, equipped with Zen imaging software) with a plan-neofluar $\times 63 / 1.3$ oil immersion objective.

\subsection{Tumor Cell Endothelial Cell Interaction}

To evaluate tumor cell adhesion, HUVEC were transferred to 6-well multiplates in complete HUVEC medium. Once the cells had reached confluence, A498, Caki-1, or KTCTL-26 cells were detached from the culture flasks by accutase treatment (PAA Laboratories, Cölbe, Germany), and $0.5 \times 10^{6}$ cells were added to the HUVEC monolayer. After $0.5,1$, or $2 \mathrm{~h}$, non-adherent tumor cells were washed off using warmed $\left(37^{\circ} \mathrm{C}\right) \mathrm{PBS}+\left(\mathrm{Ca}^{2+}\right.$ and $\left.\mathrm{Mg}^{2+}\right)$. The remaining cells were fixed with $1 \%$ glutaraldehyde. Adherent tumor cells were then counted in five different observation fields of a defined size $\left(5 \times 0.25 \mathrm{~mm}^{2}\right)$ using a phase contrast microscope and the mean cellular adhesion rate was calculated.

\subsection{Attachment to Immobilized Collagen}

Six-well plates were coated with collagen G (extracted from calfskin, consisting of $90 \%$ collagen type I and 10\% collagen type III; Biochrom, Berlin, Germany; diluted to $400 \mu \mathrm{g} / \mathrm{mL}$ in PBS) overnight at $4{ }^{\circ} \mathrm{C}$. Plastic dishes served as background control. Subsequently, plates were incubated for one $\mathrm{h}$ with $1 \%$ BSA in PBS to block nonspecific cell adhesion. $0.5 \times 10^{6}$ tumor cells were then added to each well and allowed to attach for $60 \mathrm{~min}$ at $37^{\circ} \mathrm{C}$. Subsequently, non-adherent tumor cells were washed off, the remaining adherent cells were fixed with $1 \%$ glutaraldehyde and counted microscopically. The mean cellular adhesion rate, defined by adherent cells $s_{\text {coated well }}$ - adherent cells $s_{\text {background, }}$, was calculated from five different observation fields $\left(5 \times 0.25 \mathrm{~mm}^{2}\right)$.

\subsection{Chemotaxis and Migration}

Serum induced chemotactic movement was examined using 6-well Transwell chambers (Greiner, Frickenhausen, Germany) with $8 \mu \mathrm{m}$ pores. $0.5 \times 10^{6} \mathrm{~A} 498$, Caki1, or KTCTL-26 cells $/ \mathrm{mL}$ were placed in the upper chamber in serum-free medium. The lower chamber contained $10 \%$ serum. To evaluate cell migration, Transwell chambers were pre-coated with collagen $(400 \mu \mathrm{g} / \mathrm{mL})$ and tumor cells then added. After $24 \mathrm{~h}$ incubation, the upper surface of the Transwell membrane was gently wiped with a cotton swab to remove cells that had not migrated. Cells that had moved to the lower surface of the membrane were stained using hematoxylin and counted microscopically. The mean chemotaxis and migration rate were then calculated from five different observation fields $\left(5 \times 0.25 \mathrm{~mm}^{2}\right)$. 


\subsection{Integrin Surface Expression}

Tumor cells were washed in blocking solution (PBS, 0.5\% BSA) and then incubated for $60 \mathrm{~min}$ at $4{ }^{\circ} \mathrm{C}$ with phycoerythrin (PE)-conjugated monoclonal antibodies directed against the following integrin subtypes: anti- $\alpha 1$ (mouse IgG1; clone SR84; \#559596), anti- $\alpha 2$ (mouse IgG2a; clone 12F1-H6; \#555669), anti- $\alpha 3$ (mouse IgG1; clone C3II.1; \#556025), anti- $\alpha 4$ (mouse IgG1; clone 9F10; \#555503), anti- $\alpha 5$ (mouse IgG1; clone IIA1; \#555617), anti- $\alpha 6$ (mouse IgG2a; clone GoH3; \#555736), anti- $\beta 1$ (mouse IgG1; clone MAR4; \#555443), anti- $\beta 3$ (mouse IgG1; clone VI-PL2; \#555754) or anti- $\beta 4$ (rat IgG2b; clone 439-9B; \#555720) (all from BD Pharmingen, Heidelberg, Germany). Integrin expression of tumor cells was then measured using a FACScan (BD Biosciences; FL-2H (log) channel histogram analysis; $1 \times 10^{4}$ cells/scan) and expressed as mean fluorescence units (MFU). Mouse IgG1-PE (MOPC-21; \#555749), IgG2a-PE (G155-178; \#555574), and rat IgG2b-PE (R35-38; \#555848; all from BD Biosciences) were used as isotype controls.

\subsection{Western Blotting}

To investigate integrin content, tumor cell lysates were applied to a $7-12 \%$ polyacrylamide gel (depending on the protein size) and electrophoresed for about $90 \mathrm{~min}$ at $100 \mathrm{~V}$. The protein was then transferred to nitrocellulose membranes. After blocking with non-fat dry milk for $1 \mathrm{~h}$, the membranes were incubated overnight with the following antibodies: integrin $\alpha 1$ (rabbit, polyclonal, 1:1,000; \#AB1934; Chemicon/Millipore GmbH, Schwalbach, Germany), integrin $\alpha 2$ (mouse IgG1, 1:250, clone 2; \#611017; BD Biosciences), integrin $\alpha 3$ (rabbit, polyclonal, 1:1000; \#AB1920; Chemicon/Millipore GmbH), integrin $\alpha 4$ (mouse, 1:200, clone: C-20; \#sc-6589; Santa Cruz Biotechnology, Inc., Santa Cruz, CA, USA), integrin $\alpha 5$ (mouse IgG2a, 1:5000, clone 1; \#610634; BD Biosciences), integrin $\alpha 6$ (rabbit, 1:200, clone H-87; \#sc-10730; Santa Cruz Biotechnology, Inc.), and integrin $\beta 1$ (mouse IgG1, 1:2500, clone 18; \#610468), integrin $\beta 3$ (mouse IgG1, 1:2500, clone 1; \#611141) and integrin $\beta 4$ (mouse IgG1, 1:250, clone 7; \#611233) (all from BD Biosciences). HRP-conjugated goat anti-mouse IgG and HRP-conjugated goat anti-rabbit IgG (both 1:5000; Upstate Biotechnology, Lake Placid, NY, USA) served as secondary antibodies. Additionally, integrin-related signaling was explored by anti-integrin-linked kinase (ILK) (clone 3, dilution 1:1000; \#611803), anti-focal adhesion kinase (FAK) (clone 77, dilution 1:1000; \#610088), and anti-p-specific FAK (pY397; clone 18, dilution 1:1000; \#611807) antibodies (all from BD Biosciences). HRP-conjugated goat-anti-mouse IgG (dilution 1:5000; Upstate Biotechnology) served as the secondary antibody. The membranes were briefly incubated with ECL detection reagent (ECL ${ }^{\mathrm{TM}}$; Amersham, GE Healthcare, München, Germany) to visualize the proteins and then analyzed with the Fusion FX7 system (Peqlab, Erlangen, Germany). $\beta$-actin (1:1000; Sigma-Aldrich) served as the internal control.

Gimp 2.8 software was used to perform pixel density analysis of the protein bands. The ratio of protein intensity $/ \beta$-actin intensity was calculated and expressed as percentage difference, related to controls set to $100 \%$.

\subsection{Blocking Experiments}

To determine whether the integrins $\alpha 3, \alpha 5, \beta 1$, and $\beta 3$ impact metastatic spread, A498, Caki-1, or KTCTL-26 cells were incubated for $60 \mathrm{~min}$ with $10 \mu \mathrm{g} / \mathrm{mL}$ function-blocking anti-integrin $\alpha 3$ (clone P1B5), anti-integrin $\alpha 5$ (clone P1D6), anti-integrin $\beta 1$ (clone 6S6), or anti-integrin $\beta 3$ (clone B3A) mouse $\mathrm{mAb}$ (all from Millipore). Controls were incubated with cell culture medium alone. Subsequently, tumor cell adhesion to immobilized collagen, as well as chemotaxis, was evaluated as described above.

\subsection{Statistics}

Curcumin uptake, adhesion, chemotaxis, and migration experiments were performed six times, and statistical significance was determined with the Wilcoxon-Mann-Whitney-U-test. Western bloting was done three times and statistics evaluated by t-test. Values are means $\pm \mathrm{SD}$. Differences were considered statistically significant at a p-value less than 0.05 . 


\section{Conclusions}

Since it is technically feasible to apply visible light during tumor resection, combining curcumin application with visible light could enhance the RCC treatment protocol, and compensate for the low bioavailability and rapid degradation of curcumin. The data presented here indicate a curcumin uptake within $1 \mathrm{~h}$. This time window should be considered during surgery, e.g., by infusing curcumin $1 \mathrm{~h}$ prior to light application in future RCC in vivo models.

Supplementary Materials: The following are available online at http://www.mdpi.com/2072-6694/12/2/302/s1, Figure S1: Whole western blots for Figure 7, Figure S2: Pixel density values for Figure 8.

Author Contributions: Conceptualization, A.B. and R.A.B.; Investigation, J.R., S.J., S.M., S.K., and N.Z.; Methodology, S.K. and R.A.B.; Project administration, R.A.B.; Supervision, F.K.-H.C., A.B., and R.A.B.; Visualization, J.R., S.K., F.K.-H.C., and R.A.B.; Writing - original draft, J.R. and R.A.B.; Writing - review and editing, B.B., A.B., F.K.-H.C., and R.A.B. All authors have read and agreed to the published version of the manuscript.

Funding: This work was supported by the Brigitta \& Norbert Muth Stiftung, Wiesbaden, Germany, the Friedrich-Spicker-Stiftung, Wuppertal, Germany, and a Wolfgang Lutzeyer grant of the Deutsche Gesellschaft für Urologie (German Society of Urology), grant ID RuJ1/WL-18.

Acknowledgments: The authors would like to thank Karen Nelson for language editing and proofreading.

Conflicts of Interest: The authors declare no conflict of interest.

\section{References}

1. Bray, F.; Ferlay, J.; Soerjomataram, I.; Siegel, R.L.; Torre, L.A.; Jemal, A. Global cancer statistics 2018: GLOBOCAN estimates of incidence and mortality worldwide for 36 cancers in 185 countries. CA Cancer J. Clin. 2018, 68, 394-424. [CrossRef]

2. Wang, D.-L.; Lan, J.-H.; Chen, L.; Huang, B.; Li, Z.; Zhao, X.-M.; Ma, Q.; Sheng, X.; Li, W.-B.; Tang, W.-X. Integrin-linked Kinase Functions as a Tumor Promoter in Bladder Transitional Cell Carcinoma. Asian Pac. J. Cancer Prev. 2012, 13, 2799-2806. [CrossRef]

3. Van Zijl, F.; Krupitza, G.; Mikulits, W. Initial steps of metastasis: Cell invasion and endothelial transmigration. Mutat. Res. 2011, 728, 23-34. [CrossRef]

4. Deutsche Krebshilfe, Deutschland. Die blauen Ratgeber: Nierenkrebs. Antworten. Hilfen. Perspektiven; Deutsche Krebshilfe, Deutschland: Bonn, Germany, 2014.

5. Kroeger, N.; Choueiri, T.K.; Lee, J.-L.; Bjarnason, G.A.; Knox, J.J.; MacKenzie, M.J.; Wood, L.; Srinivas, S.; Vaishamayan, U.N.; Rha, S.-Y.; et al. Survival outcome and treatment response of patients with late relapse from renal cell carcinoma in the era of targeted therapy. Eur. Urol. 2014, 65, 1086-1092. [CrossRef]

6. Umer, M.; Mohib, Y.; Atif, M.; Nazim, M. Skeletal metastasis in renal cell carcinoma: A review. Ann. Med. Surg. 2018, 27, 9-16. [CrossRef]

7. Zentrum fur Krebsregisterdaten. Available online: http://www.rki.de/Krebs/DE/Content/Krebsarten/ Nierenkrebs/nierenkrebs_node.html (accessed on 12 December 2019).

8. Ljungberg, B.; Campbell, S.C.; Choi, H.Y.; Cho, H.Y.; Jacqmin, D.; Lee, J.E.; Weikert, S.; Kiemeney, L.A. The epidemiology of renal cell carcinoma. Eur. Urol. 2011, 60, 615-621. [CrossRef]

9. Mani, J.; Juengel, E.; Arslan, I.; Bartsch, G.; Filmann, N.; Ackermann, H.; Nelson, K.; Haferkamp, A.; Engl, T.; Blaheta, R.A. Use of complementary and alternative medicine before and after organ removal due to urologic cancer. Patient Prefer. Adherence 2015, 9, 1407-1412. [CrossRef]

10. Huebner, J.; Micke, O.; Muecke, R.; Buentzel, J.; Prott, F.J.; Kleeberg, U.; Senf, B.; Muenstedt, K. User rate of complementary and alternative medicine (CAM) of patients visiting a counseling facility for CAM of a German comprehensive cancer center. Anticancer Res. 2014, 34, 943-948.

11. Bose, S.; Panda, A.K.; Mukherjee, S.; Sa, G. Curcumin and tumor immune-editing: Resurrecting the immune system. Cell Div. 2015, 10, 6. [CrossRef]

12. Panda, A.K.; Chakraborty, D.; Sarkar, I.; Khan, T.; Sa, G. New insights into therapeutic activity and anticancer properties of curcumin. J. Exp. Pharmacol. 2017, 9, 31-45. [CrossRef] 
13. Kronski, E.; Fiori, M.E.; Barbieri, O.; Astigiano, S.; Mirisola, V.; Killian, P.H.; Bruno, A.; Pagani, A.; Rovera, F.; Pfeffer, U.; et al. miR181b is induced by the chemopreventive polyphenol curcumin and inhibits breast cancer metastasis via down-regulation of the inflammatory cytokines CXCL1 and -2. Mol. Oncol. 2014, 8, 581-595. [CrossRef]

14. Bachmeier, B.E.; Killian, P.H.; Melchart, D. The Role of Curcumin in Prevention and Management of Metastatic Disease. Int. J. Mol. Sci. 2018, 19, 1716. [CrossRef]

15. Sa, G.; Das, T. Anti cancer effects of curcumin: Cycle of life and death. Cell Div. 2008, 3, 14. [CrossRef]

16. Aggarwal, B.B.; Sung, B. Pharmacological basis for the role of curcumin in chronic diseases: An age-old spice with modern targets. Trends pharmacol. Sci. 2009, 30, 85-94. [CrossRef]

17. Bhattacharyya, S.; Mandal, D.; Sen, G.S.; Pal, S.; Banerjee, S.; Lahiry, L.; Finke, J.H.; Tannenbaum, C.S.; Das, T.; $\mathrm{Sa}, \mathrm{G}$. Tumor-induced oxidative stress perturbs nuclear factor-kappaB activity-augmenting tumor necrosis factor-alpha-mediated T-cell death: Protection by curcumin. Cancer Res. 2007, 67, 362-370. [CrossRef]

18. Bernd, A. Visible light and/or UVA offer a strong amplification of the anti-tumor effect of curcumin. Phytochem. Rev. 2014, 13, 183-189. [CrossRef]

19. Anand, P.; Kunnumakkara, A.B.; Newman, R.A.; Aggarwal, B.B. Bioavailability of curcumin: Problems and promises. Mol. Pharm. 2007, 4, 807-818. [CrossRef]

20. Burgos-Morón, E.; Calderón-Montaño, J.M.; Salvador, J.; Robles, A.; López-Lázaro, M. The dark side of curcumin. Int. J. Cancer 2010, 126, 1771-1775. [CrossRef]

21. Muddineti, O.S.; Kumari, P.; Ray, E.; Ghosh, B.; Biswas, S. Curcumin-loaded chitosan-cholesterol micelles: Evaluation in monolayers and 3D cancer spheroid model. Nanomedicine (Lond.) 2017, 12, 12. [CrossRef]

22. Schiborr, C.; Kocher, A.; Behnam, D.; Jandasek, J.; Toelstede, S.; Frank, J. The oral bioavailability of curcumin from micronized powder and liquid micelles is significantly increased in healthy humans and differs between sexes. Mol. Nutr. Food Res. 2014, 58, 516-527. [CrossRef]

23. Bulboacă, A.E.; Boarescu, P.M.; Bolboacă, S.D.; Blidaru, M.; Feștilă, D.; Dogaru, G.; Nicula, C.A. Comparative Effect Of Curcumin Versus Liposomal Curcumin On Systemic Pro-Inflammatory Cytokines Profile, MCP-1 And RANTES In Experimental Diabetes Mellitus. Int. J. Nanomed. 2019, 14, 8961-8972. [CrossRef]

24. Wang, Z.S.; Chen, L.Z.; Zhou, H.P.; Liu, X.H.; Chen, F.H. Diarylpentadienone derivatives (curcumin analogues): Synthesis and anti-inflammatory activity. Bioorganic Med. Chem. Lett. 2017, 27, 1803-1807. [CrossRef]

25. Feng, T.; Wei, Y.; Lee, R.J.; Zhao, L. Liposomal curcumin and its application in cancer. Int. J. Nanomed. 2017, 12, 6027-6044. [CrossRef]

26. Rutz, J.; Maxeiner, S.; Juengel, E.; Bernd, A.; Kippenberger, S.; Zöller, N.; Chun, F.K.-H.; Blaheta, R.A. Growth and Proliferation of Renal Cell Carcinoma Cells Is Blocked by Low Curcumin Concentrations Combined with Visible Light Irradiation. Int. J. Mol. Sci. 2019, 20, 1464. [CrossRef]

27. Ghorbani, J.; Rahban, D.; Aghamiri, S.; Teymouri, A.; Bahador, A. Photosensitizers in antibacterial photodynamic therapy: An overview. Laser Ther. 2018, 27, 293-302. [CrossRef]

28. Laubach, V.; Kaufmann, R.; Bernd, A.; Kippenberger, S.; Zöller, N. Extrinsic or Intrinsic Apoptosis by Curcumin and Light: Still a Mystery. Int. J. Mol. Sci. 2019, 20, 905. [CrossRef]

29. Bruzell, E.M.; Morisbak, E.; Tønnesen, H.H. Studies on curcumin and curcuminoids. XXIX. Photoinduced cytotoxicity of curcumin in selected aqueous preparations. XXIX. Photoinduced cytotoxicity of curcumin in selected aqueous preparations. Photochem. Photobiol. Sci. 2005, 4, 523-530. [CrossRef]

30. Moharrami Kasmaie, F.; Jahromi, Z.; Gazor, R.; Zaminy, A. Comparison of melatonin and curcumin effect at the light and dark periods on regeneration of sciatic nerve crush injury in rats. EXCLI J. 2019, 18, 653-665.

31. Niu, T.; Tian, Y.; Cai, Q.; Ren, Q.; Wei, L. Red Light Combined with Blue Light Irradiation Regulates Proliferation and Apoptosis in Skin Keratinocytes in Combination with Low Concentrations of Curcumin. PLoS ONE 2015, 10, e0138754. [CrossRef]

32. Bessone, F.; Argenziano, M.; Grillo, G.; Ferrara, B.; Pizzimenti, S.; Barrera, G.; Cravotto, G.; Guiot, C.; Stura, I.; Cavalli, R.; et al. Low-dose curcuminoid-loaded in dextran nanobubbles can prevent metastatic spreading in prostate cancer cells. Nanotechnology 2019, 30, 214004. [CrossRef]

33. Herman, J.G.; Stadelman, H.L.; Roselli, C.E. Curcumin blocks CCL2 induced adhesion, motility and invasion, in part, through down-regulation of CCL2 expression and proteolytic activity. Int. J. Oncol. 2009, 34, 1319-1327. [PubMed] 
34. Zheng, B.-Z.; Liu, T.-D.; Chen, G.; Zhang, J.-X.; Kang, X. The effect of curcumin on cell adhesion of human esophageal cancer cell. Eur. Rev. Med. Pharmacol. Sci. 2018, 22, 551-560. [PubMed]

35. Wu, J.; Lu, W.-Y.; Cui, L.-L. Inhibitory effect of curcumin on invasion of skin squamous cell carcinoma A431 cells. Asian Pac. J. Cancer Prev. 2015, 16, 2813-2818. [CrossRef] [PubMed]

36. Yodkeeree, S.; Ampasavate, C.; Sung, B.; Aggarwal, B.B.; Limtrakul, P. Demethoxycurcumin suppresses migration and invasion of MDA-MB-231 human breast cancer cell line. Eur. J. Pharmacol. 2010, 627, 8-15. [CrossRef]

37. Mu, J.; Wang, X.; Dong, L.; Sun, P. Curcumin derivative L6H4 inhibits proliferation and invasion of gastric cancer cell line BGC-823. J. Cell. Biochem. 2019, 120, 1011-1017. [CrossRef]

38. Hu, C.; Li, M.; Guo, T.; Wang, S.; Huang, W.; Yang, K.; Liao, Z.; Wang, J.; Zhang, F.; Wang, H. Anti-metastasis activity of curcumin against breast cancer via the inhibition of stem cell-like properties and EMT. Phytomedicine 2019, 58, 152740. [CrossRef]

39. Zhang, H.; Zheng, J.; Shen, H.; Huang, Y.; Liu, T.; Xi, H.; Chen, C. Curcumin Suppresses In Vitro Proliferation and Invasion of Human Prostate Cancer Stem Cells by Modulating DLK1-DIO3 Imprinted Gene Cluster MicroRNAs. Genet. Test. Mol. Biomarkers 2018, 22, 43-50. [CrossRef]

40. Wang, L.; Han, L.; Tao, Z.; Zhu, Z.; Han, L.; Yang, Z.; Wang, H.; Dai, D.; Wu, L.; Yuan, Z.; et al. The curcumin derivative WZ35 activates ROS-dependent JNK to suppress hepatocellular carcinoma metastasis. Food Funct. 2018, 9, 2970-2978. [CrossRef]

41. Li, Y.; Wang, P.; Chen, X.; Hu, J.; Liu, Y.; Wang, X.; Liu, Q. Activation of microbubbles by low-intensity pulsed ultrasound enhances the cytotoxicity of curcumin involving apoptosis induction and cell motility inhibition in human breast cancer MDA-MB-231 cells. Ultrason. Sonochem. 2016, 33, 26-36. [CrossRef]

42. Holy, J. Curcumin inhibits cell motility and alters microfilament organization and function in prostate cancer cells. Cell Motil. Cytoskeleton. 2004, 58, 253-268. [CrossRef]

43. Dhar, G.; Chakravarty, D.; Hazra, J.; Dhar, J.; Poddar, A.; Pal, M.; Chakrabarti, P.; Surolia, A.; Bhattacharyya, B. Actin-curcumin interaction: Insights into the mechanism of actin polymerization inhibition. Biochemistry 2015, 54, 1132-1143. [CrossRef] [PubMed]

44. Radhakrishnan, V.M.; Kojs, P.; Young, G.; Ramalingam, R.; Jagadish, B.; Mash, E.A.; Martinez, J.D.; Ghishan, F.K.; Kiela, P.R. pTyr421 cortactin is overexpressed in colon cancer and is dephosphorylated by curcumin: Involvement of non-receptor type 1 protein tyrosine phosphatase (PTPN1). PLoS One 2014, 9, e85796. [CrossRef] [PubMed]

45. Mierke, C.T.; Frey, B.; Fellner, M.; Herrmann, M.; Fabry, B. Integrin $\alpha 5 \beta 1$ facilitates cancer cell invasion through enhanced contractile forces. J. Cell Sci. 2011, 124, 369-383. [CrossRef] [PubMed]

46. Desgrosellier, J.S.; Cheresh, D.A. Integrins in cancer: Biological implications and therapeutic opportunities. Nat. Rev. Cancer 2010, 10, 9-22. [CrossRef] [PubMed]

47. Markovic-Lipkovski, J.; Brasanac, D.; Müller, G.A.; Müller, C.A. Cadherins and integrins in renal cell carcinoma: An immunohistochemical study. Tumori 2001, 87, 173-178. [CrossRef]

48. Feldkoren, B.; Hutchinson, R.; Rapoport, Y.; Mahajan, A.; Margulis, V. Integrin signaling potentiates transforming growth factor-beta 1 (TGF- $\beta 1$ ) dependent down-regulation of E-Cadherin expression - Important implications for epithelial to mesenchymal transition (EMT) in renal cell carcinoma. Exp. Cell res. 2017, 355, 57-66. [CrossRef]

49. Wang, J.-R.; Liu, B.; Zhou, L.; Huang, Y.-X. MicroRNA-124-3p suppresses cell migration and invasion by targeting ITGA3 signaling in bladder cancer. Cancer Biomark. 2019, 24, 159-172. [CrossRef]

50. Sakaguchi, T.; Yoshino, H.; Yonemori, M.; Miyamoto, K.; Sugita, S.; Matsushita, R.; Itesako, T.; Tatarano, S.; Nakagawa, M.; Enokida, H. Regulation of ITGA3 by the dual-stranded microRNA-199 family as a potential prognostic marker in bladder cancer. Br. J. Cancer 2018, 118, e7. [CrossRef]

51. Bogusławska, J.; Rodzik, K.; Popławski, P.; Kędzierska, H.; Rybicka, B.; Sokół, E.; Tański, Z.; Piekiełko-Witkowska, A. TGF- $\beta 1$ targets a microRNA network that regulates cellular adhesion and migration in renal cancer. Cancer Lett. 2018, 412, 155-169. [CrossRef]

52. Hase, H.; Jingushi, K.; Ueda, Y.; Kitae, K.; Egawa, H.; Ohshio, I.; Kawakami, R.; Kashiwagi, Y.; Tsukada, Y.; Kobayashi, T.; et al. LOXL2 status correlates with tumor stage and regulates integrin levels to promote tumor progression in ccRCC. Mol. Cancer Res. 2014, 12, 1807-1817. 
53. Erdem, M.; Erdem, S.; Sanli, O.; Sak, H.; Kilicaslan, I.; Sahin, F.; Telci, D. Up-regulation of TGM2 with ITGB1 and SDC4 is important in the development and metastasis of renal cell carcinoma. Urol. Oncol. 2014, 32, 25.e13-20. [CrossRef] [PubMed]

54. Conti, A.; Santoni, M.; Amantini, C.; Burattini, L.; Berardi, R.; Santoni, G.; Cascinu, S.; Muzzonigro, G. Progress of molecular targeted therapies for advanced renal cell carcinoma. BioMed Res. Int. 2013, 2013, 419176. [CrossRef] [PubMed]

55. Cooper, J.; Giancotti, F.G. Integrin Signaling in Cancer: Mechanotransduction, Stemness, Epithelial Plasticity, and Therapeutic Resistance. Cancer Cell 2019, 35, 347-367. [CrossRef] [PubMed]

56. Haake, S.M.; Li, J.; Bai, Y.; Kinose, F.; Fang, B.; Welsh, E.A.; Zent, R.; Dhillon, J.; Pow-Sang, J.M.; Chen, Y.A.; et al. Tyrosine Kinase Signaling in Clear Cell and Papillary Renal Cell Carcinoma Revealed by Mass Spectrometry-Based Phosphotyrosine Proteomics. Clin. Cancer Res. 2016, 22, 5605-5616. [CrossRef]

57. Bao, Y.; Yang, F.; Liu, B.; Zhao, T.; Xu, Z.; Xiong, Y.; Sun, S.; Le, Q.; Wang, L. Angiopoietin-like protein 3 blocks nuclear import of FAK and contributes to sorafenib response. Br. J. Cancer 2018, 119, 450-461. [CrossRef]

58. Hu, B.; Sun, D.; Sun, C.; Sun, Y.-F.; Sun, H.-X.; Zhu, Q.-F.; Yang, X.-R.; Gao, Y.-B.; Tang, W.-G.; Fan, J.; et al. A polymeric nanoparticle formulation of curcumin in combination with sorafenib synergistically inhibits tumor growth and metastasis in an orthotopic model of human hepatocellular carcinoma. Biochem. Biophys. Res. Commun. 2015, 468, 525-532. [CrossRef]

59. Debata, P.R.; Begum, S.; Mata, A.; Genzer, O.; Kleiner, M.J.; Banerjee, P.; Castellanos, M.R. Curcumin potentiates the ability of sunitinib to eliminate the VHL-lacking renal cancer cells 786-O: Rapid inhibition of $\mathrm{Rb}$ phosphorylation as a preamble to cyclin D1 inhibition. Anticancer Agents Med. Chem. 2013, 13, 1508-1513. [CrossRef]

60. Neuschmelting, V.; Kim, K.; Malekzadeh-Najafabadi, J.; Jebiwott, S.; Prakash, J.; Scherz, A.; Coleman, J.A.; Kircher, M.F.; Ntziachristos, V. WST11 Vascular Targeted Photodynamic Therapy Effect Monitoring by Multispectral Optoacoustic Tomography (MSOT) in Mice. Theranostics 2018, 8, 723-734. [CrossRef]

61. Kroeze, S.G.C.; Grimbergen, M.C.M.; Rehmann, H.; Bosch, J.L.H.R.; Jans, J.J.M. Photodynamic therapy as novel nephron sparing treatment option for small renal masses. J. Urol. 2012, 187, 289-295. [CrossRef]

62. Ellerkamp, V.; Bortel, N.; Schmid, E.; Kirchner, B.; Armeanu-Ebinger, S.; Fuchs, J. Photodynamic Therapy Potentiates the Effects of Curcumin on Pediatric Epithelial Liver Tumor Cells. Anticancer Res. 2016, 36, 3363-3372.

(C) 2020 by the authors. Licensee MDPI, Basel, Switzerland. This article is an open access article distributed under the terms and conditions of the Creative Commons Attribution (CC BY) license (http://creativecommons.org/licenses/by/4.0/). 